\title{
DETERMINANTS OF ACCESS TO CREDIT BY COCOA FARMERS IN OSUN STATE, NIGERIA
}

\author{
J.T.O. Oke, A.D. Kehinde* and A.J. Akindele
}

Received 1 October 2019, Revised 18 December 2019, Accepted 24 December 2019, Published online 31 December 2019

\begin{abstract}
This study investigated the determinants of access to credit among cocoa farmers in Osun state, Nigeria. Specifically, the study described the socio-economic characteristics of cocoa farmers in the study area, examined the factors affecting access to credit by cocoa farmers in the study area; and identified the constraints faced by cocoa farmers in credit acquisition. The study was conducted in Osun state, south-western Nigeria. A multi-stage sampling procedure was used for selecting respondents for this study. A total number of 180 farmers were selected for the study. Data were analyzed using Descriptive statistics and logit Regression. The results for the entire respondents showed average values of 46 years for age, 25 years for year of experience, 8 persons for household size, and about $88 \%$ of the respondents have formal education. Farm size $(\mathrm{p}<0.05)$, income $(\mathrm{p}<0.05)$ and years of schooling $(\mathrm{p}<0.05)$ show significant and positive effects on access to credit. On the other hand, gender $(\mathrm{p}<0.05)$, distance to credit source $(\mathrm{p}<0.1)$ and interest rate $(\mathrm{p}<0.01)$ are significant but have negative effects on access to credit by cocoa farmers in the study area. Majority (85.6\%) of the cocoa farmers acknowledged lack of collateral security as a constraint in credit acquisition, while about $71.1 \%$ acknowledged that high interest rate was a factor hindering credit acquisition. Other factors are acknowledged in the following order: Bureaucratic procedures $60.6 \%$, lack of information about available credit sources $45 \%$, mode of repayment $40 \%$, no credit association $31.1 \%$ and non- membership of farmers'based organization had $23.3 \%$. Following the findings of the study, government, nongovernmental agencies and financial institutions should provide cocoa farmers with adequate access to credit facilities and soft loans with low interest and without collateral security. In addition, cocoa farmers should be educated on the acquisition of credit.
\end{abstract}

Keywords: Determinants, Access to Credit, Cocoa Farmers, Osun State.

Department of Agricultural Economics, Faculty of Agriculture, Obafemi Awolowo University, Ile Ife, Osun State, Nigeria.

*Corresponding author's email: kehindeayodeji8@gmail.com (A.D. Kehinde)

Cite this article as: Oke, J.T.O. Kehinde, A.D. and Akindele, A.J. 2019. Determinants of access to credit by cocoa farmers in Osun state, Nigeria. Int. J. Agril. Res. Innov. Tech. 9(2): 57-61. DOI: 10.3329/ijarit.v9i2.45411.

\section{Introduction}

Cocoa (Theobroma cacao), is of importance to the State of Osun in terms of its foreign exchange earning ability. With respect to employment, it offers a number of people employment both directly and indirectly. It is also served as a source of raw materials to industries, as well as source of revenue to the governments of cocoa producing states (Nkang et al., 2007). Despite the potentials of cocoa to the economy, it is interesting but unfortunate to note that the trend of cocoa production in Nigeria is been declining. This could be attributed to low productivities on individual cocoa farms among other problems (Daniel, 2009). Consequently, low productivities have been attributed to lack of access to credit among other factors. Several authors (Ike and Umuedafe, 2013; Nwachukwu et al., 2010; Idowu et al., 2007) have noted that inadequate access to credit is prominent among cocoa farmers in Nigeria. This has kept cocoa farming at the subsistence level and has serious on the outcomes of the farmers (Nwankwo, 2004; Oladeebo and Oladeebo, 2008). Efforts have been made by Government to delivering credit services to cocoa farmers through a number of programmes (Ugbajah and Ugwumba, 2013).

Despite this, credit is still insufficient among cocoa farmers due to some factors (Abedullah et al, 2009; Eze et al., 2010; Adebayo and Adeola, 2008; Ajagbe, 2012; Ololade and Olagunju, 2013; Akpan et al., 2013). Following from this, this study investigated the determinants of access to credit among cocoa farmers in Osun State 
Specifically, the study described the socioeconomic characteristics of cocoa farmers in the study area, determined the factors affecting access to credit by cocoa farmers in the study area; and identified the constraints faced by cocoa farmers in credit acquisition.

\section{Methodology}

\section{Study area}

The Study area is Osun State carved out of Oyo State on 27 August 1991 with Osogbo as the state capital. It lies between latitude 7 and $30^{\circ} \mathrm{N}$ and longitude 4 and $30^{\circ} \mathrm{E}$. The State shares interstate boundaries with Kwara State in the North, Ogun State in the south, Oyo State in the west and Ondo State in the east. The State has a landmass of about 9,251 km². It is currently made up of 30 Local Government Areas (LGAs). Osun State is divided into 3 Agricultural zones by Osun State Agricultural Development Project (OSSADEP) viz., Osogbo, Iwo and Ife/Ijesha. Estimates in the recently released provisional figures of the 2005 census put Osun State human population at 4.137627 million (NBS, 2006). The State exhibits the typical tropical climate with prominent wet and dry seasons with fertile soil, which encourages the production of crops cocoa, maize, yam, cassava, millet, rice, plantain and cashew. The rainy season generally occur between April and October while the dry season occurs between November and March. The mean annual temperature in the State varies between $21.1^{\circ} \mathrm{C}$ and $31.1^{\circ} \mathrm{C}$. The mean temperature is highest at the end of the harmattan, which is from the middle of January to the onset of the rains. Rainfall figures over the State vary from an average of $1000 \mathrm{~mm}$ in the derived savannah agro-ecology to $1200 \mathrm{~mm}$ in the rain forest at the onset of heavy rains to $1600 \mathrm{~mm}$ at its peak in the rain forest part of the State.

\section{Sampling procedure and sample size}

A multistage sampling procedure was used to select 180 respondents for the study. The first stage involved the purposive selection of one agricultural development zone out of the three agricultural development zones in the State. The selection was based on the predominance of cocoa production in the zone. The second stage involved the simple random selection of six Local Government Areas out of the ten Local Government Areas in the agricultural zone. The third stage involved the simple random selection of two villages from each of the Local Government Areas. In the last stage, 15 cocoa farmers were randomly selected from each of the villages giving a total of 180 cocoa farmers used for the study.

\section{Analytical technique}

Descriptive statistics and logit regression model were used to analyze the collected data.

\section{Descriptive statistics}

Descriptive statistics (mean, percentages and frequency distribution) were used to describe the socioeconomic characteristics of cocoa farmers and constraints faced in credit acquisition in the study area.

\section{Logit regression model}

Binary logit model was used to analyzed the determinant factors affecting farmer's access to credit.

Explicitly, it expressed as follows:

$Y=\beta_{0}+\beta_{1} X_{1}+\beta_{2} X_{2}+\beta_{3} X_{3}+\beta_{4} X_{4}+\beta_{5} X_{5}+\beta_{6} X_{6}+\beta_{7} X_{7}+$

$\beta_{8} X_{8}+\beta_{9} X_{9}+\beta_{10} X_{10}+e \quad \ldots . \quad 2$

Where, $\mathrm{Y}=($ " 1 " if respondent has access to credit and " $O$ " if respondent has no access to credit).

$\mathrm{X}_{1}=$ Gender ( 1 if male, $\mathrm{O}$ if female); $\mathrm{X}_{2}=$ Farming experience (years); $\mathrm{X}_{3}=$ Extension contact ( 1 if respondent receives extension services, 0 if otherwise); $\mathrm{X}_{4}=$ Interest rate (\%); $\mathrm{X}_{5}=$ Distance between the lender and borrower $(\mathrm{km}) ; \mathrm{X}_{6}=$ Farm size (hectares); $X_{7}=$ Group membership ( 1 if the respondent is a member of a farmer based organization (FBO), $\mathrm{O}$ if otherwise); $\mathrm{X}_{8}=$ total income from farming in the last cropping season (naira); $\mathrm{X}_{9}=$ Literacy status ( 1 if respondent has formal education, $\mathrm{O}$ if otherwise); $\mathrm{X}_{10}=$ Access to guarantor ( 1 if respondent has access, 0 if otherwise)

$\mathrm{e}=$ error term

\section{Results and Discussion}

\section{Socio-economic characteristics of cocoa farmers}

The socio-economic characteristics of the respondents were presented in Table 1. Majority $(79 \%)$ of the farmers were male. This is in conformity with the findings of Ololade and Olagunju (2013). About 91\% of the respondents were married. This finding is in line with Onyenucheya (2005). The mean age of sampled farmers was 46.3 years. This indicates that on the average, the respondents are within the active and productive age group, likely to source for credit to improve their production. This is in line with the findings of Oni et al. (2005). Majority (88\%) of the respondents had formal education. The mean household size in the study area was 8 persons. This is in conformity with Ololade and Olagunju (2013). The mean years of experience was 24.9 years. This study reveals that majority of the respondents were highly experienced in cocoa farming. According to the Table, majority of the cocoa farmers (57.8\%) in the study area had farm sizes of 2-4 hectares. This is in conformity with the findings of Akanni and Dada (2012). About $65 \%$ of the farmers in the study area were involved in fulltime farming. This shows that the predominant occupation of respondents in the 
study area is farming and they earn most of their income from farming activities. This tallies with Arigbo and Ifenkwe (2013). A smaller percentage
(40\%) of the farmers in the study area had access to credit.

Table 1. Socio-economic Characteristics of Cocoa Farmers.

\begin{tabular}{|l|l|}
\hline Variables & Cocoa Farmers \\
\hline Age (years) & $46.15( \pm 12.73)$ \\
\hline Male (\%) & 79.00 \\
\hline Married (\%) & 91.00 \\
\hline Formal education (\%) & 88.00 \\
\hline Household size (\#) & $8.12( \pm 3.97)$ \\
\hline Access to credit & 40.00 \\
\hline Farm size (ha) & 12.80 \\
\hline Less than 2 & 57.80 \\
\hline $2-4$ & 21.10 \\
\hline More than 5 & $24.90( \pm 13.62)$ \\
\hline Years of farming experience & 65.00 \\
\hline Primary occupation (\%) & \\
\hline
\end{tabular}

Source: Field survey, 2017

\section{Determinants of access to credit by cocoa farmers}

The determinants of access to credit by cocoa farmers were presented in Table 2. The Rsquared value for the determinants of access to credit was $67.90 \%$. This suggests that $67.90 \%$ of the variability in the access to credit of the respondents is jointly explained by variations in the specified independent variables in the model. Years of schooling was statistically significant at $5 \%$ with positive effects on access to credit by cocoa farmers in the study area. This implies that an increase in years of schooling increases the likelihood of accessing credit. This finding concurs with the findings of Hussein (2007). The total annual income was statistically significant at $5 \%$ level with positive effects on access to credit by cocoa farmers in the study area. This implies that an increase in total income in the study area will lead to an increase in the likelihood of accessing credit. This result conforms to the findings of Ojo (2005). Farm size was statistically significant at $5 \%$ with positive effects on access to credit by cocoa farmers in the study area. This implies that an increase in farm size would lead to an increase in the likelihood of accessing credit by cocoa farmers in the study area. On the other hand, gender was statistically significant at $5 \%$ level with negative effects on access to credit by cocoa farmers in the study area. This implies that being a male reduces the likelihood of accessing credit by cocoa farmers in the study area. This is in line with the findings of Ololade and Olagunju (2013). Distance to credit source was statistically significant at $10 \%$ level with negative effects on access to credit to credit, this implies that the likelihood of accessing credit in the study area increases with a decrease in distance to the nearest financial services provider. This is in conformity with the findings of Hussein (2007). Interest rate was statistically significant at $1 \%$ level with negative effects on access to credit. This implies that the likelihood of accessing credit in the study area decreases as the interest rate charged on credit increases. This is in line with the findings of Ololade and Olagunju (2013).

Table 2. Determinants of access to credit by cocoa farmers.

\begin{tabular}{|l|l|l|}
\hline Variables & Coefficient & P-value \\
\hline Gender & $-3.815^{* *}$ & 0.031 \\
\hline Farm experience & -0.070 & 0.183 \\
\hline Extension services & -4.579 & 0.642 \\
\hline Farm size & $0.938^{* * *}$ & 0.026 \\
\hline Group membership & -0.601 & 0.786 \\
\hline Income & $0.000^{* *}$ & 0.032 \\
\hline Education level & $0.749^{* *}$ & 0.016 \\
\hline Collateral security & -15.057 & 0.999 \\
\hline Interest rate & $-5.029^{* * *}$ & 0.001 \\
\hline Distance & $-0.287^{* *}$ & 0.068 \\
\hline $\mathrm{R}^{2}$ & 0.679 & \\
\hline
\end{tabular}

Source: Field survey, 2017

$\mathrm{NB}:{ }^{*}$ significant at $10 \%,{ }^{* *}$ significant at $5 \%,{ }^{* * *}$ significant at $1 \%$. 


\section{Constraints affecting farmers access to credit}

Table 3 showed that majority (85.6\%) of the cocoa farmers acknowledged lack of collateral security as a constraint in credit acquisition, while about $71.1 \%$ acknowledged that high interest rate was a factor hindering credit acquisition. Other factors were acknowledged in the following order: Bureaucratic procedures $60.6 \%$, lack of information about available credit sources $45.0 \%$, mode of repayment $40.0 \%$, no credit association $31.1 \%$ and non-membership of cooperatives had $23.3 \%$.

Table 3. Frequency and percentage distribution of problems faced by cocoa farmers in credit access.

\begin{tabular}{|l|l|l|}
\hline Constraints & Frequency* & Percentage \\
\hline High interest rate & 128 & 71.1 \\
\hline Lack of collateral security & 154 & 85.6 \\
\hline Lack of information about available credit sources & 81 & $45 \cdot 0$ \\
\hline Bureaucratic procedures in credit acquisition & 109 & 60.6 \\
\hline Non-membership of farmers' based organization & 42 & 23.3 \\
\hline No credit association & 56 & 31.1 \\
\hline Mode of repayment & 72 & 40.0 \\
\hline
\end{tabular}

Source: Field survey, 2017

* Multiple response

\section{Conclusion}

The study concluded that cocoa is one of the major cash crops vastly produced in the study area with more male farmers than female farmers. Cocoa production was undertaken by smallholder farmers with large household sizes and vast experience in cocoa farming. Majority of the cocoa farmers had access to credit in the study area. The major determinants of access to credit by cocoa farmers in the study area were farm size, income, gender, education level, distance to credit source and interest rate. Cocoa farmers with larger farm sizes, more years of schooling as well as higher annual incomes were more likely to access credit in the study area. On the other hand, male farmers in the study area were unlikely to access credit. Also, high interest rate charged on loans decreased chances of accessing credit in the study area. Farmers were less likely to access credit from credit institutions that were farther away from them. The major constraints faced by farmers in accessing credit in the study area were lack of collateral security, high interest rate and bureaucratic procedures in accessing credit. Following the findings of the study, government, non-governmental agencies and financial institutions should provide cocoa farmers with adequate access to credit facilities and soft loans with low interest. In addition, cocoa farmers should be educated on the acquisition of credit.

\section{References}

Abedullah, A., Mahmood, N. and Kouser, S. 2009. The role of agricultural credit in the growth of livestock sector: A case study of Faisalabad. Pakistan Vet. J. 29(2): 81-84.

Adebayo, O.O. and Adeola, R.G. 2008. Sources and Uses of Agric Credit by Small Scale Farmers in Surulere LGA of Oyo State. Anthropol. 10(4): 313-314.
Ajagbe, F.A. 2012. Analysis of Access to and Demand for Credit by Small Scale Entrepreneurs. Evidence from Oyo State, Nigeria. J. Emerg. Trends Econ. Manage. Sci. 3(3): 180-183.

Akanni, K.A. and Dada, A.O. 2012. Analysis of labour use patterns among small-holder cocoa farmers in south western Nigeria. $J$. Agril. Sci. Tech. B. 2: 107-113.

Akpan, S.B., Inimfon, V.P., Samuel, J.U., Edem, A.O. and Uwemedimo, E.O. 2013. Determinants of Credit Access and Demand among Poultry Farmers in AkwaIbom State, Nigeria. American J. Expt. Agric. 3(2): 293307.

Arigbo, P. and Ifenkwe, G. 2013. Farm Decision Making Among Cocoa Farming Households in Ikwuano L.G.A of AbiaState. Nigeria. Int. J. Acad. Res. Prog. Edu. Dev. 2(1): 275-286.

Daniel, A. 2009. Problems and Prospects of Commercial Small and Medium Scale Cocoa and Oil Palm Production in Cross River States Nigeria. B.Sc Thesis, Department of Agricultural Economics and Extension, Enugu State University of Science and Technology.

Eze, C.C., Lemechi, J.I., Ugochukwu, A.I., Eze, V.C., Awulonu, C.A.O. and Okon, A.X. 2010. Agricultural Financing Policies and Rural Development in Nigeria. pp. 1-20. In: Proc. of the $84^{\text {th }}$ Annual Conference of the Agricultural Economics Society Edinburgh, Scotland held on March 29-31, 2010.

Hussein, H. 2007. Farm Household Economic Behaviour in Imperfect Financial Markets. Doctoral Thesis, Department of Economics, Swedish University of Agricultural Sciences. 41p. http://pub.epsilon.slu.se/1563/1/HHKfino. pdf Accessed on March 20, 2011. 
Idowu, E.O, Osuntogun, D.A. and Oluwasola, O. 2007. Effects of Market Deregulation on Cocoa (Theobroma cacao) Production in Southwest Nigeria. African J. Agril. Res. 2(9): 429-434.

Ike, P.C. and Umuedafe, D.E. 2013. Determinants of Savings and Capital Formation among Rural Farmers in Isoko North Local Government Area of Delta State, Nigeria Asian Econ. Fin. Rev. 3(10): 1289-1297.

NBS (National Bureau of Statistics). 2006. Population Census. National Bureau of Statistics: Federal Republic of Nigeria, Abuja.

Nkang, N.M., Eucharia, A.A., Sylvanus, O.A. and Eyo, O.E. 2007. Investment in cocoa production in Nigeria: a cost and return analysis of three cocoa production management systems in the cross-river state cocoa belt. Cent. Euro. J. Agric. 8(1): 81-90.

Nwachukwu, I.N., Nnanna, A., Jude, N. and Imonikhe, G. 2010. Competitiveness and Determinants of Cocoa Export from Nigeria. Int. J. Food Agril. Econ. 2(3): 51-54.

Nwankwo, U.M. 2004. Impact of community banks on Women Farmers Poverty Level in Rural Abia State Nigeria. M.Sc Thesis, Department of Agricultural Economics, Abia State University, Uturu.
Ojo, J.A.T. 2005. Central Banking and Financial Sector Management in Nigeria; An Outsider view. In: Fakiyesi, O.O. and S.O. Akano (Eds), Issues in Money, Finance and Economic Management in Nigeria (Essays in Honour of Professor Obasanmi Olakankpo). pp. $35-98$.

Oladeebo, J.O. and Oladeebo, O.E. 2008. Determinant of loan repayment among small holders' farmers in Ogbomoso Agricultural Zone of Oyo State, Nigeria. J. Soc. Sci. 17(1): 59-62.

Ololade, R.A. and Olagunju, F.I. 2013. Determinants of Access to Credit among Rural Farmers in Oyo State, Nigeria. Glob. J. Sci. Front. Res. Agric. Vet. Sci. 13(2): 17-21.

Oni, O.A., Oladele, O.I. and Oyewole, I.K. 2005. Analysis of factors influencing loan Default among Poultry farmers in Ogun State, Nigeria. J. Cent. Euro. Agric. 6(4): 619-624.

Onyenucheya, F. 2005. Determinants of Loan Repayment by farmers under the Nigeria Agricultural Cooperative and Rural Bank in Abia State. MSc Project Report, Michael Okpara University of Agriculture, Umudike.

Ugbajah, M. and Ugwumba, C. 2013. Analysis of Micro Credit as a Veritable Tool for Poverty Reduction among Rural Farmers in Anambra State, Nigeria. Discourse J. Agric. Food Sci. 1(10): 152-159. 